\title{
Absence of Serum-Stimulated Lipase Activity and Altered Lipid Content in Milk from a Patient with Type I Hyperlipoproteinaemia
}

\author{
G. M. B. BERGER, ${ }^{(48)}$ A. SPARK, P. M. BAILLIE, J. HUSKISSON, G. STOCKWELL, AND \\ E. VAN DER MERWE \\ Department of Chemical Pathology, Red Cross War Memorial Children's Hospital, and Fishing Industry Research \\ Institute, Cape Town, South Africa
}

\section{Summary}

We measured the serum-stimulated lipase activity, fatty acid content, and various biochemical parameters in the breast milk of a lactating mother suffering from familial lipoprotein lipase deficiency and of healthy control subjects. Serum-stimulated lipase activity was virtually undetectable in milk from our patient and the total fatty acid content was low. The fatty acid composition differed from normal showing a marked absolute and relative increase in the content of lauric (C12:0) and myristic (C14:0) fatty acids and considerably reduced levels of oleic (C18:1) and especially linoleic (C18:2) acids. Other fatty acid species showed lesser changes in concentration. Besides a reduced calcium concentration in the milk from our patient, other biochemical parameters were not significantly different from control subjects.

\section{Abbreviations}

apo CII, apolipoprotein C

AT-LPL, adipose tissue lipoprotein lipase

EFA, essential fatty acid

HL, hepatic lipase

LPL, lipoprotein lipase

NEFA, non-esterified fatty acids

SSL, serum-stimulated lipoprotein lipase

A SSL is found in the mammary glands and breast milk of human (15) and other species including the rat (30), cow $(8,21)$, guinea pig $(28,37)$, and goat $(45)$. Milk SSL resembles adipose AT-LPL with respect to substrate specificity, molecular weight, susceptibility to inhibition by $1.0 \mathrm{M}$ sodium chloride or protamine sulfate, dependence on apo CII for activity and immunologic specificity $(25,32)$. The presumed identity of the two enzymes has not, however, been verified in terms of amino acid composition, and the enzymes are reciprocally regulated by prolactin, which is a powerful and rapid inducer of SSL synthesis but represses the adipose tissue enzyme (46). Evidence derived from animal studies $(1,2,4,11)$ and from manipulation of the fat intake of lactating mothers (20), indicates that plasma triglyceride of dietary origin, dependent presumably on mammary gland LPL activity $(25,27$, $28,31,39$ ), makes a substantial contribution to milk lipid production. Scow et al. (40) have proposed that triglyceride present in chylomicrons and in very low density lipoprotein are hydrolysed at the capillary endothelial cell surface with liberation of fatty acids, partial glycerides, and glycerol that find their way into alveolar cells by diffusion in the plane of the membrane. Other sources of milk fatty acid include de novo synthesis within the mammary gland and uptake of NEFA from the plasma, derived ultimately from depot fat stores $(20,27)$.

A patient under our care, with the typical clinical and biochemical features of type I hyperlipoproteinaemia $(10,16)$, recently became pregnant and was delivered of a normal male offspring. We were able to obtain milk for lipase assay and for the determination of lipid content on three separate occasions. Our results suggest that milk SSL and AT-LPL depend on a common or closely-related genetic locus for normal synthesis and that mammary gland SSL is an important determinant of the composition of milk lipid.

\section{MATERIALS AND METHODS}

Case report. Our patient, Mrs. N, was a 33-year-old female of Asiatic extraction with a history of repeated episodes of abdominal pain of undetermined origin since childhood. Shortly after her marriage, ten years before this study, Mrs. $\mathrm{N}$ gave birth to a normal infant but since that time has had irregular menses and menorrhagia, and has had one documented miscarriage. Clinical and haematological examination failed to reveal significant abnormality except for a persistent splenomegaly and a mild normochromic anaemia. A slightly raised plasma bilirubin level and marked lipaemia were the only abnormalities present in routine biochemistry. A chest x-ray, intravenous pyelography, and a barium meal were normal. A tentative diagnosis of type I hyperlipoproteinaemia was made and the patient was referred to the Lipid Clinic for confirmation and for further management of the lipid disorder.

Fasting plasma obtained on initial examination at the Lipid Clinic was markedly turbid, and, on standing for $24 \mathrm{~h}$, resolved into a thick creamy layer over a turbid infranatent. Her plasma cholesterol level was $7.31 \mathrm{mmole} / \mathrm{liter}(274 \mathrm{mg} / \mathrm{d} l)$ and plasma triglyceride was $42.2 \mathrm{mmole} / \mathrm{liter}(3734 \mathrm{mg} / \mathrm{d} l)$. LPL and HL activities were determined in plasma after the intravenous administration of 40 units of heparin per kilogram. The results (Table 1) showed a virtually complete absence of LPL activity thus confirming the diagnosis. Her husband and 10-year-old son both have normal plasma lipid values. The patient was placed on a low fat diet resulting in a fall of her plasma triglyceride level to 5.49 mmole/liter.

Mrs. N was successfully treated for her infertility by means of clomiphene citrate [Clomid, Mer-National Laboratories (Pty.) Ltd.]. Gestation was uneventful except for spotting at $7 \mathrm{wk}$, which responded to a short course of chorionic gonadotrophin [Pregnyl, 
Table 1. Total lipolytic activity in post-heparin plasma from $\mathrm{Mrs}$. $N$ and six control subjects ${ }^{1}$

\begin{tabular}{lccc}
\hline & PHLA $^{2}$ & $\begin{array}{c}\text { Lipoprotein } \\
\text { lipase }\end{array}$ & $\begin{array}{c}\text { Hepatic } \\
\text { lipase }\end{array}$ \\
\hline Mrs N & 8.0 & 0.8 & 7.8 \\
Controls & 24.1 & 11.0 & 12.9 \\
& $(20.1-32.0)$ & $(6.0-14.3)$ & $(10.2-17.7)$ \\
\hline
\end{tabular}

\footnotetext{
${ }^{1}$ Enzyme activity expressed as $\mu$ mole fatty acid liberated per $\mathrm{h}$ per $\mathrm{ml}$ serum.

${ }^{2}$ PHLA, post-heparin plasma lipolytic activity measured 10 min after the intravenous injection of $40 \mathrm{IU}$ heparin per kg. Figures in parentheses give the range.
}

Organon (Pty.) Ltd.]. Despite attempts at restriction of fat intake, the patient's triglyceride levels rose to $146 \mathrm{mmole} / \mathrm{liter}(12920$ $\mathrm{mg} / \mathrm{dl})$. Due to the presence of meconium staining, Caesarean section was performed with the delivery of a full-term normal male infant. Assay of cord blood yielded normal triglyceride values. The infant was breast-fed for the first week of life but developed loose stools, alleviated by supplementing the breast milk with a soya-based formula [Isomil, Abbot Laboratories S.A. (Pty.) Ltd.]. A temporary reduction in lactation was overcome by decreasing the Isomil intake and by the administration of Metoclopramide BP (Maxolon, Beecham Research Laboratories). A low fat diet was recommended to our patient during the postpartum period but close questioning indicated that compliance was poor. Plasma triglyceride was $48.0 \mathrm{mmole} / \mathrm{liter}(4248 \mathrm{mg} / \mathrm{dl})$ immediately after delivery, and $42.0 \mathrm{mmole} / \mathrm{liter}(3717 \mathrm{mg} / \mathrm{dl})$ some months later. She eventually discontinued breast feeding after 5 wk for personal reasons.

Collection of milk. Milk was obtained by means of an electrically driven suction pump (Medap Breast Pump, Hamburg, FGR) from Mrs. $\mathrm{N}$ and from healthy mothers approximately matched for age, days after delivery, and ethnic origin. The volumes obtained were 25-70 $\mathrm{ml}$ except for one 10-ml sample from Mrs. $\mathrm{N}$ and from a control subject. Milk was generally collected after completion of feeding from the contralateral breast and was immediately placed on ice for transportation to the laboratory where it was stored at $-70^{\circ} \mathrm{C}$. Informed consent to these procedures was freely granted by all participants.

Enzyme assay. Milk SSL was partially purified essentially according to the procedure described by Hernell and Olivecrona (17). Twelve ml of milk was centrifuged at $20,000 \times \mathrm{g} 30 \mathrm{~min}$ in a Beckman L5-65 ultracentrifuge using the SW 27 rotor. The creamy layer was collected by tube slicing and was washed once through saline under the same conditions. The washed cream was delipidated with acetone-diethyl ether and then lyophilised. Before assay the powder was redissolved in $0.7 \mathrm{ml}$ of a $0.27 \mathrm{M}$ ammonium chloride buffer at $\mathrm{pH} 8.6$ and the undissolved residue sedimented by centrifugation.

Assay of the SSL was carried out by determining the release of labelled fatty acids from $\left[{ }^{14} \mathrm{C}\right]$-triolein (38). The substrate mixture comprised the following components dissolved in $0.2 \mathrm{M}$ Tris- $\mathrm{HCl}$ buffer, $\mathrm{pH}$ 8.2: $5 \mathrm{~g} / 100 \mathrm{ml}$ defatted bovine serum albumin [Fraction V, Miles Laboratories (Pty.) Ltd., R.S.A.], Triton X-100 (0.06 $\mathrm{g} / 100 \mathrm{ml})$, sodium chloride $(0.125 \mathrm{M})$, calcium chloride $(2.5 \mathrm{mM})$, magnesium chloride $(0.8 \mathrm{mM}), 5 \mathrm{mg} / \mathrm{ml}$ Triolein [P-L Biochemicals Inc., Milwaukee, WI, cat. no. 967432], and glycerol tri $\left[1{ }^{14} \mathrm{C}\right]$ oleate $(50 \mathrm{mCi} / \mathrm{mmole}$, Amersham International Ltd., Amersham, U.K.) in an amount sufficient to give $0.1 \mu \mathrm{Ci}$ per assay tube. The mixture was sonicated for $4 \mathrm{~min}$, in $10-\mathrm{sec}$ bursts to allow for cooling. After 30 min stabilization at room temperature, $0.55 \mathrm{ml}$ of the substrate was mixed with $0.05 \mathrm{ml}$ of the milk enzyme solution and $0.05 \mathrm{ml}$ of plasma obtained from a pool of normal donors as source of activator. Each sample was also assayed without activator by substituting $0.05 \mathrm{ml}$ of normal saline; in some instances, $1.2 \mathrm{M}$ sodium chloride was included in the reaction mixture. The assays were performed in duplicate for $60 \mathrm{~min}$ at $37^{\circ} \mathrm{C}$. The reaction was stopped by means of an isopropanol/ $\mathrm{H}_{2} \mathrm{SO}_{4}$ mixture and the liberated fatty acids were extracted first into hexane and then into $\mathrm{KOH}$ to which was added $5 \mathrm{ml}$ Instagel (Packard Instrument Co., Inc., IL, U.S.A.) for counting in a liquid scintillation spectrometer (Packard Instrument Co. Inc., IL., U.S.A.). In all experiments recovery of released fatty acid was determined using $\left[{ }^{14} \mathrm{C}\right]$-oleic acid and the appropriate controls and blanks were included. The release of $\left[{ }^{14} \mathrm{C}\right]$-fatty acid was linear over $60 \mathrm{~min}$ and enzyme activity was expressed as $\mu$ mole free fatty acid released per hour per $\mathrm{m} l$ milk.

Plasma LPL and HL activities were assayed in the post-heparin plasma from our patient and control subjects using the identical assay procedure. Discrimination between HL and LPL was achieved by means of specific blocking antibodies to the HL essentially according to Huttunen et al. (18).

Lipid analysis. Gas-liquid chromatography was used to determine the total fatty acid content and composition of milk from Mrs. N and five controls. Small aliquots $(200 \mu \mathrm{l})$ of milk were extracted into chloroform and saponified in methanolic sodium hydroxide followed by derivitization with $14 \%$ boron trifluoride in methanol. After the addition of hexane and cooling, the solution was saturated with sodium chloride. The hexane layer, containing the derivitized fatty acids, was dried by means of anhydrous sodium sulfate and injected directly into the gas chromatograph. Aliquots containing $1 \mathrm{mg}$ of eicosanoic acid (C20:0), added as internal standard, were treated in an identical manner. Separation was carried out either on packed columns $(2 \times 16 \mathrm{~mm}$ glass, $10 \%$ DEGS on chromosorb W $80 / 100$ ) or on glass capillary columns (12 $\mathrm{m}$ silane $10 \mathrm{CP}$ or $40 \mathrm{~m}$ OV-73). The running conditions for the packed columns were $130^{\circ} / 4^{\circ} / \mathrm{min} / 220^{\circ}$ and for the capillary columns were $150^{\circ} / 4^{\circ} / \mathrm{min} / 240^{\circ}$. Carrier gases were nitrogen at a flow rate of $30 \mathrm{ml} / \mathrm{min}$ for the packed column and hydrogen (v $=30 \mathrm{~cm} / \mathrm{s}$ ) for the capillary columns. A Hewlett-Packard 3353 data system was used to quantitate the peaks.

Each sample was run with and without internal standard, which allowed for the calculation of total fatty acid content and the absolute amounts of each component. On five samples a comparison was carried out between the total triglyceride content determined enzymatically using a kit (Boehringer Mannheim GmbH, cat. no. 125032), the total lipid content determined by means of gravimetric analysis (9) and the total fatty acid content determined as above. The fatty acid assay yielded slightly higher but essentially equivalent results to the other two methods. This is compatible with the major contribution made by the fatty acid component to total milk lipid $(23,24)$.

General. All other assays were performed using standard laboratory procedures. Reagent grade chemicals were used throughout unless specifically stated otherwise. Statistical significance was estimated during the $\mathrm{zM}$ test (26) for comparing a random sample of one or more measurements with a parent group whose mean and standard deviation is known.

\section{RESULTS}

Milk SSL. Milk from Mrs. N, obtained on the 2nd and 8th day after delivery, contained less than $0.1 \%$ of the SSL activity present in the milk of seven control subjects (Table 2). Omission of preheparin plasma from the incubation mixture resulted in an $80 \%$ reduction in the lipase activity measured in milk from the control subjects. Addition of excess sodium chloride to a final concentration of $1.2 \mathrm{M}$ to the milk from three controls caused a $60-90 \%$ inhibition of enzyme activity, thus further confirming the specificity of the assay for SSL activity. Milk SSL activity in the control subjects showed no obvious correlation with duration of lactation (Table 2).

Lipid content and composition. Milk fatty acid content and composition from five control subjects and from Mrs. $\mathrm{N}$ are compared in Table 3. Although the mean fatty acid content of the three samples from Mrs. $N$ was lower than that of the five controls, the difference was not significant. Very substantial and significant 
differences were, however, observed in the content of specific fatty acids. The absolute and relative levels of the C12:0 and C14:0 fatty acids were substantially elevated in Mrs. N $(P<0.002)$; conversely C18:1 and especially C18:2 fatty acid were markedly lower in Mrs. $\mathbf{N}$ compared with the control subjects. Other less pronounced changes were a reduced proportion and content of C16:1 in the milk from Mrs. N $(P<0.05)$ and a low absolute content of $\mathrm{C} 20: 1(P<0.05)$. The proportions of the saturated long-chain fatty acids palmitic (16:0) and stearic (C18:0) were essentially identical in our patient and the control group.

General milk chemistry. Table 4 lists a number of biochemical parameters measured in milk from Mrs. $\mathrm{N}$ and eight control subjects. The calcium concentration in milk from Mrs. $\mathrm{N}$ was lower than that of the control subjects $(P<0.05)$, but other differences did not reach significance.

Table 2. Serum-stimulated lipase (SSL) activity in the breast milk of Mrs $N$ and six control subjects ${ }^{1}$

\begin{tabular}{lccc}
\hline & & \multicolumn{2}{c}{ SSL activity } \\
\cline { 3 - 4 } Subject & $\begin{array}{c}\text { Days } \\
\text { postpartum }\end{array}$ & Fully assay & - PEH $^{2}$ \\
\hline Mrs N & 2 & 0.063 & 0.00 \\
& 8 & 0.0086 & 0.01 \\
Control 1 & 2 & 52.1 & 19.9 \\
2 & 3 & 13.9 & 1.16 \\
3 & 3 & 47.1 & 8.63 \\
& 7 & 76.7 & 13.4 \\
4 & 19 & 76.4 & 12.2 \\
5 & 26 & 60.6 & 8.17 \\
& & 54.4 & $10.6(19.4 \%$ of mean $)$ \\
\hline
\end{tabular}

${ }^{1}$ Enzyme activity expressed as $\mu$ mole fatty acid liberated per $\mathrm{h}$ per $\mathrm{ml}$ milk.

${ }^{2} \mathrm{PEH}$, pre-heparin plasma from normal donors.

\section{DISCUSSION}

Milk serum-stimulated lipase. The concomitant absence or severe reduction of post-heparin plasma LPL and milk-SSL activities has not previously been reported, other than in a brief reference to unpublished work (16). The LPL deficiency in the post-heparin plasma of our patient cannot be attributed to a lack of apo CII because normal human plasma was added to all assays as a source of activator. These data suggest that a common or closely related genetic locus is implicated in the normal synthesis and secretion of the milk and adipose tissue enzymes and strengthen the evidence favouring a close structural similarity between them.

The origin of milk SSL activity is not certain. Adipocytes within the mammary gland would, a priori, appear to be the most likely source. LPL activity has, however, been demonstrated on the external surface of alveolar cells obtained from lactating rat mammary gland (6). Pregnancy is associated with marked regression of mammary gland adipose tissue and with the concomitant proliferation of ductal and alveolar elements (44). Furthermore, prolactin has reciprocal effects on mammary gland and adipose tissue LPL activities (46). These observations suggest that the alveolar cell should be considered a potential source of milk SSL (14). The increase in mammary gland LPL (Milk SSL) in later pregnancy and lactation is such as to play a significant role in the clearance of circulating triglyceride in the rat $(14,33)$.

Lipid content and composition. A number of studies suggests that in many species de novo synthesis from acetate accounts for most of the $\mathrm{Cl} 4$ or shorter chain-length fatty acids present in milk, whereas palmitate (C16:0) and, to a greater extent, the longer chain fatty acids arise mainly from circulating lipoprotein-triglyceride under the action of mammary gland SSL $(1,31,39,41)$. The degree to which fatty acids liberated from triglyceride within the mammary gland first contribute to the local NEFA pool $(1,4)$ or, alternatively, are transported directly in the plane of the membrane to the alveolar cell (40) is unknown. NEFA derived from

Table 3. The fatty acid content and composition of milk from $M r s ~ N$ and five control subjects

\begin{tabular}{|c|c|c|c|c|c|c|c|c|c|c|}
\hline Subject & $\begin{array}{c}\text { Days } \\
\text { postpartum }\end{array}$ & $\begin{array}{c}\text { Total fatty acid } \\
\text { content }\end{array}$ & \multicolumn{8}{|c|}{ Individual fatty acids in milk: absolute concentration $(\mathrm{g} / \mathrm{dl})$ and $\%$ composition } \\
\hline Mrs N & 8 & 1.42 & 0.212 & 0.237 & 0.293 & 0.023 & 0.104 & 0.347 & 0.103 & 0.011 \\
\hline \multirow[t]{2}{*}{ Mrs N } & 10 & 1.75 & 0.308 & 0.331 & 0.345 & 0.057 & 0.126 & 0.359 & 0.147 & 0.013 \\
\hline & & & $(17.0)$ & $(20.2)$ & $(20.1)$ & $(1.5)$ & $(7.4)$ & $(20.3)$ & $(7.5)$ & $(0.44)$ \\
\hline Mrs N & 30 & 2.02 & 0.347 & 0.427 & 0.382 & 0.035 & 0.147 & 0.417 & 0.188 & 0.011 \\
\hline Mean & & & $(15.8)$ & $(19.7)$ & $(20.1)$ & $(2.0)$ & $(7.5)$ & $(21.2)$ & (7.4) & $(0.61)$ \\
\hline \multirow[t]{2}{*}{ Control } & 3 & 2.89 & 0.092 & 0.172 & 0.602 & 0.666 & 0.268 & 0.966 & 0.498 & 0.042 \\
\hline & & & $(4.4)$ & $(6.2)$ & $(20.8)$ & $(2.3)$ & $(8.6)$ & $(32.0)$ & $(16.4)$ & (1.3) \\
\hline \multirow[t]{2}{*}{ Control } & 5 & 3.23 & 0.142 & 0.211 & 0.699 & 0.115 & 0.224 & 1.052 & 0.497 & 0.043 \\
\hline & & & $(4.7)$ & $(6.8)$ & $(21.8)$ & $(3.2)$ & $(7.0)$ & $(33.1)$ & $(16.2)$ & $(0.8)$ \\
\hline Control & & & $(5.7)$ & $(7.5)$ & $(21.1)$ & $(2.8)$ & $(9.3)$ & $(30.0)$ & $(14.2)$ & (1.42) \\
\hline \multirow[t]{2}{*}{ Mean } & & 2.62 & 0.118 & 0.158 & 0.548 & 0.084 & 0.202 & 0.865 & 0.435 & 0.037 \\
\hline & & & $(4.7)$ & $(6.0)$ & $(20.8)$ & $(3.2)$ & $(7.4)$ & $(32.8)$ & $(16.1)$ & $(1.2)$ \\
\hline \multicolumn{2}{|c|}{$\mathrm{Z}$ value (absolute concentration) } & 1.51 & 5.34 & 3.48 & 1.60 & 2.42 & 1.04 & 2.76 & 3.25 & 2.27 \\
\hline \multicolumn{2}{|c|}{ Significance level $(P)$} & NS & $<0.002$ & $<0.002$ & NS & $<0.05$ & NS & $<0.01$ & $<0.01$ & $<0.05$ \\
\hline \multicolumn{2}{|c|}{$Z$ value (\% composition) } & & 18.5 & 10.5 & 0.9 & 2.00 & 0.07 & 6.1 & 5.1 & 1.2 \\
\hline \multicolumn{2}{|c|}{ Significance level $(P)$} & & $<0.002$ & $<0.002$ & NS & $<0.05$ & NS & $<0.002$ & $<0.002$ & NS \\
\hline
\end{tabular}

${ }^{1}$ Because quantitatively minor contributions were omitted from this table, the summated figures in each row are slightly lower than the total fatty acid content $(\mathrm{g} / \mathrm{dl})$. The $\%$ composition for each fatty acid is given in parentheses. 
Table 4. Biochemistry of milk from Mrs $N$ and eight control subjects

\begin{tabular}{|c|c|c|c|c|c|c|c|}
\hline Subject & $\underset{\text { (mmole/liter) }}{\text { Sodium }}$ & $\begin{array}{c}\text { Potassium } \\
\text { (mmole/liter) }\end{array}$ & $\begin{array}{c}\text { Chloride } \\
\text { (mmole/liter) }\end{array}$ & $\begin{array}{c}\text { Magnesium } \\
\text { (mmole/liter) }\end{array}$ & $\begin{array}{c}\text { Calcium } \\
\text { (mmole/liter) }\end{array}$ & $\mathrm{pH}$ & $\begin{array}{c}\text { Total protein } \\
(\mathrm{g} / \mathrm{l})\end{array}$ \\
\hline Mrs N (3) & $\begin{array}{c}18.7 \\
(14-24)^{1}\end{array}$ & $\begin{array}{c}17.7 \\
(15-19)\end{array}$ & $\begin{array}{c}24.7 \\
(21-29)\end{array}$ & $\begin{array}{c}0.95 \\
(0.89-1.01)\end{array}$ & $\begin{array}{c}4.39 \\
(3.54-4.88)\end{array}$ & $\begin{array}{c}7.51 \\
(7.40-7.70)\end{array}$ & $\begin{array}{c}17.6 \\
(17.1-18.0)\end{array}$ \\
\hline$Z$ value & 0.37 & 0.42 & 1.72 & 1.69 & 2.47 & 1.78 & 0.47 \\
\hline $\begin{array}{l}\text { Significance } \\
\text { level }(P)\end{array}$ & NS & NS & $(<0.1)$ & $(<0.1)$ & $(<0.05)$ & $(<0.1)$ & NS \\
\hline
\end{tabular}

${ }^{1}$ Figures in parentheses give range.

adipose tissue would appear to contribute relatively small amounts to mammary gland lipid synthesis except when on a low fatcalorie restricted diet (20).

The total lipid of milk is influenced by the manner and timing of collection as well as by biologic and environmental factors (22, $23,24)$. Hind-milk contains substantially more fat than fore-milk and the lipid content is lowest in the morning reaching a peak at midday or later. Colostrum has less lipid than mature milk (36). In the present study milk was collected by means of a mechanical pump in mid-morning and substantial volumes were generally obtained so as to minimize fluctuation consequent on the stage of feeding. Approximate matching of controls and Mrs. $\mathrm{N}$ with respect to the period of lactation, also reduced artefactual differences. Despite the fact that the difference in lipid content between Mrs. $\mathrm{N}$ and the five control subjects did not achieve statistical significance, the $1.73 \mathrm{~g} / \mathrm{d} l$ of total fat in the milk from our patient was lower than the mean value found in lactating mothers from 15 poorly nourished communities (22). This result is compatible with evidence that in the human (27), as in many other species $(25,28,31,37,40,45)$ the provision of fatty acids from the triglyceride-rich lipoproteins, mediated by mammary gland SSL, is an important source of milk lipid.

Contrary to the physiologic lability of total lipid content, the composition of milk fat is independent of the time of collection, stage of feeding, stage of lactation, or normal variations in diet intake $(13,19)$. One exception to the above generalization is the strong correlation between dietary EFA content and the levels of EFA in milk lipids $(12,20,30,34)$. Another is the marked elevation of C12:0 and C14:0 fatty acids observed in the milk of a lactating mother subjected to a severely restricted fat intake ( $<3 \mathrm{~g} /$ day) in the presence of excess carbohydrate (20). The low level of the EFA, C18:2, and to a somewhat less marked degree, of the other long-chain, unsaturated fatty acids in the milk of Mrs $\mathrm{N}$, is compatible with her reduced ability to mobilize these species from circulating lipoprotein triglyceride due to the absence of mammary gland LPL. Substrate availability was not a limiting factor because the triglyceride concentration in her plasma was consistently and markedly elevated; thus, circulating NEFA derived from adipose tissue, or possibly from post-prandial chyle, are presumably the major source of the EFA in the milk of our patient. Significant contribution of depot fat to the $\mathrm{C18:2}+3$ content of milk, under conditions of restricted intake, was demonstrated by Insull et al. (20). The same compensatory mechanism may also account for part of the long-chain, non-essential fatty acid in our patient's milk; however, increased local synthesis probably plays an additional role in view of the smaller deviation of stearate (18:0) and oleate (18:1) from normal compared with linoleate (18:2).

The strongest evidence for a compensatory enhancement of fatty acid synthesis within the mammary gland comes from the marked absolute and relative increase in the $\mathrm{C} 12: 0$ and $\mathrm{C} 14: 0$ content, which constituted $39.5 \%$ of the total lipid in Mrs. N. compared with $10.7 \%$ in the controls. A similar elevation of lauric (C12:0) and myristic (C14:0) acids was previously observed in a lactating mother on an extremely low fat diet (20). The inhibition of fatty acid synthesis by long-chain fatty acids or their derivatives is well established $(5,7)$; thus, reduced transport of these species due to the absence of mammary gland LPL or severely restricted fat intake would be expected to permit enhanced fatty acid synthesis in mammary tissue. The specific spectrum of fatty acids produced is determined, at least in part, by the presence of a thioesterase unique to the mammary tissue of a number of animal species (41), including humans (43), which releases predominantly $\mathrm{C} 14$ and shorter fatty acyl chains from the fatty acid synthetase complex. Other factors possibly accounting for the fatty acid profile of milk under conditions of restricted transport from circulating triglyceride, include the activity of various fatty acyl elongating and desaturating enzyme activities present in mammary tissue $(3,29,35,42)$ and the concentration and rate of uptake of components of the circulating NEFA pool. These pathways were inadequate to maintain the normal complement of the longchain, unsaturated fatty acids in the absence of mammary gland LPL in our patient.

\section{REFERENCES AND NOTES}

1. Annison, E. F., Linzell, J. L., Fazakerley, S., and Nichols, B. W.: The oxidation and utilization of palmitate, stearate, oleate and acetate by the mammary gland of the fed goat in relation to their overall metabolism, and the role of plasma phospholipids and neutral lipids in milk-fat synthesis. Biochem. J., 102: 637 (1967).

2. Barry, J. M., Bartley, W., Linzell, J. L., and Robinson, D. S.: The uptake from the blood of triglyceride fatty acids of chylomicra and low density lipoprotein by the mammary gland of the goat. Biochem. J., 89: 6 (1963).

3. Bickerstaffe, R. and Annison, E. F.: The desaturase activity of goat and sow mammary gland. Comp. Biochem. Physiol., 35: 653 (1971)

4. Bishop, L., Davies, T., Glascock, R. F., and Welch, V. A.: Studies on the origin of milk fat: further study of bovine serum lipoproteins and an estimation of their contribution to milk fat. Biochem. J., 113: 629 (1969).

5. Bloch, K. and Vance D.: Control mechanisms in the synthesis of saturated fatty acids. Ann. Rev. Biochem., 46: 263 (1977).

6. Clegg, R. A.: Triacylglycerol hydrolysis by cells isolated from lactating rat mammary gland. Biochem. Biophys. Acta, 663: 598 (1981)

7. Donaldson, W. E.: Regulation of fatty acid synthesis. Fed. Proc., 38: 2617 (1979).

8. Egelrud, T. and Olivecrona, T.: The purification of a lipoprotein lipase from bovine skim milk. J. Biol. Chem., 247: 6212 (1972).

9. Folch, J., Lees, M., and Sloane Stanley, G. H.: A simple method for the isolation and purification of total lipids from animal tissues. J. Biol. Chem., 226: 497 (1957).

10. Frederickson, D. S., Goldstein, J. L., and Brown, M. S.: The familial hyperlipoproteinaemias. In: Stanbury, J. B. Jr., Wyngaarden, J. B. and Fredrickson, D. S. Editors: The Metabolic Basis of Inherited Disease. pp. 604-655 (Mcraw-Hill Book Co., 1978)

11. Glascock, R. F., Welch, V. A., Bishop, C., Davies, T., Wright, E. W., and Noble R. C.: An investigation of serum lipoproteins and of their contribution to milk fat in the dairy cow. Biochem. J., 88: 149 (1966)

12. Guthrie, H. A., Picciano, M. F., and Sheehe, D.: Fatty acid patterns of human milk. J. Pediatr., 90: 39 (1977).

13. Hall, B.: Uniformity of human milk. Am. J. Clin. Nutr., 32: 304 (1979)

14. Hamosh, M., Clary, T. R., Chernick, S. S., and Scow, R. O.: Lipoprotein lipase activity of adipose and mammary tissue and plasma triglyceride in pregnant and lactating rats. Biochim. Biophys. Acta, 210: 473 (1970).

15. Hamosh, M. and Scow, R. O.: Lipoprotein lipase activity in guinea pig and rat milk Biochim. Biophys. Acta, 231: 283 (1971).

16. Havel, R. J., Goldstein, J. L., and Brown, M. S.: Lipoproteins and Lipid Transport. In: Bondy, P. K. and Rosenberg, L. E., editors: Metabolic Control and Disease. p. 420 (W.B. Saunders Company, 1980).

17. Hernell, O. and Olivecrona, T.: Human milk lipase. I. Serum-stimulated lipase. J. Lipid. Res., 15: 367 (1974)

18. Huttunen, J. K., Ehnholm, G., Kerri, M., and Nikkilä, E. A.: Post-heparin plasma lipoprotein lipase and hepatic lipase in normal subjects and in patients with hypertriglyceridemia: correlation to se, age, and various parameters of triglyceride metabolism. Clin. Sci. Mol. Med., 50: 249 (1976).

19. Insull, W. Jr. and Ahrens, E. H. Jr.: The fatty acids fnof human milk from mothers on diets taken ad libitum. Biochem. J., 72: 27033 (1959). 
20. Insull, W. Jr., James, T., and Ahrens, E. H.: The fatty acids of human milk. II. Alterations produced by manipulation of caloric balance and exchange of dietary fats. J. Clin. Invest., 38: 443 (1959).

21. Iverius, P. H. and Ostlund-Lindqvist, A. M.: Lipoprotein lipase from bovine milk. J. Biol. Chem., 251: 7791 (1976)

22. Jelliffe, D. B. and Jelliffe, E. F. P.: The volume and composition of human milk in poorly nourished communities: a review. Am. J. Clin. Nutr., 31: 492 (1978).

23. Jensen, R. G., Clark, R. M., and Ferris, A. M.: Composition of lipids in human milk: a review. Lipids, 15: 345 (1980).

24. Jensen, R. G., Hagerty, M. M., and McMahon, K. E.: Lipids of human milk and infant formulas: a review. Am. J. Clin. Nutr., 31: 990 (1978).

25. Jensen, R. G. and Pitas, R. E.: Milk lipoprotein lipase: a review. J. Dairy Sci., 59: 1203 (1976).

26. Langley, R.: Practical Statistics, revised edition. p. 152-159. (Pan Books Ltd., London, 1970).

27. Linzell, J. L. and Peaker, M.: Mechanism of milk secretion. Physiol. Rev., 51: 564 (1971).

28. McBride, O. W. and Korn, E. D.: The lipoprotein lipase of mammary gland and the correlation of its activity to lactation. J. Lipid Res., 4: 17 (1963).

29. McDonald, T. M. and Kinsella, J. E.: Stearyl-Co A desaturase of bovine mammary microsomes. Arch. Biochem. Biophys., 156: 223 (1973)

30. Mellies, M. J., Ishikawa, T. T., Gartside, P. S., Burtun, K., MacGee, J., Allen, K., Steiner, P. M., Brady, D., and Glueck, C. J.: Effects of varying maternal dietary fatty acid in lactating women and their infants. Am. J. Clin. Nutr., 32: 299 (1979).

31. Mendelson, C. R., Zinder, O., Blanchette-Mackie, E. J., Chernick, S. S. and Scow, R. O.: Lipoprotein lipase and lipid metabolism in mammary gland. $\mathbf{J}$. Dairy Sci., 60: 666 (1977).

32. Nilsson-Ehle, P., Gorfinkel, A. S., and Schotz, M. C.: Lipolytic enzymes and plasma lipoprotein metabolism. Ann. Rev. Biochem., 49: 667 (1980).

33. Otway, S. and Robinson, D. S.: The significance of changes in tissue clearingfactor lipase activity in relation to the lipemia of pregnancy. Biochem. J., 106: 677 (1968).

34. Potter, J. M. and Nestel, P. J.: The effects of dietary fatty acids and cholesterol on the milk lipids of lactating women and the plasma cholesterol of breast-fed infants. Am. J. Clin. Nutre., 29: 45 (1976).
35. Rao, G. A. and Abraham, S.: Fatty acid desaturation by mammary gland microsomes from lactating mice. Lipids, 4: 269 (1974).

36. Read, W. W. C. and Sarrif, A.: Human milk lipids. I. Changes in fatty acid composition of early colostrum. Am. J. Clin. Nutr., 17: 177 (1965).

37. Robinson, D. S.: Changes in the lipolytic activity of the guinea pig mammary gland at parturition. J. Lipid Res., 4: 21 (1963).

38. Schotz, M. C., Garfinkel, A. S., Huebotter, R. J., and Steward, J. E.: A rapid assay for lipoprotein lipase. J. Lipid Res., 11: 68 (1970).

39. Scow, R. O., Blanchette-Mackie, E. J., Mendelson, C. R., Hamosh, M., and Zinder, O.: Incorporation of dietary fatty acids into milk triglyceride: mechanism and regulation. Mod. Probl. Paediatr., 15: 31 (1975).

40. Scow, R. O., Blanchette-Mackie, E. J., and Smith, L. G.: Transport of lipid across capillary endothelium. Fed. Proc., 39: 2610 (1980).

41. Smith, S.: Mechanism of chain length determination in biosynthesis of milk fatty acids. J. Dairy Sci., 63: 337 (1980).

42. Strong, C. R. and Dels, R.: Fatty acids synthesized by mammary gland slices from lactating guinea pig and rabbit. Comp. Biochem. Physiol., 43B: 643 (1972).

43. Thompson, B. J. and Smith, S.: Biosynthesis of the medium-chain fatty acids by epithelial cells from lactating human breast. Fed. Proc., 41: 352 (1982).

44. Topper, Y. J. and Freeman, C. S.: Multiple hormone interactions in the developmental biology of the mammary gland. Physiol. Rev., 60: 1049 (1980).

45. West, C. E., Bircherstaff, R., Anniso, E. I., and Linzell, J. L.: Studies on the mode of uptake of blood triglycerides by the mammary gland of the lactating goat. Biochem. J., 126: 477 (1972).

46. Zinder, O., Hamosh, M., Fleck, T. R. C., and Scow, R. O.: Effect of prolactin on lipoprotein lipase in mammary gland and adipose tissue of rats. Am. J. Pathol., 226: 744 (1974).

47. We are grateful to the Cape Provincial Administration and to the Medical Research Council (South Africa) for financial support.

48. Requests for reprints should be addressed to: Prof. G.M.B. Berger, Department of Chemical Pathology, Red Cross War Memorial Children's Hospital, Klipfontein Road, Rondebosch, Cape, 7700 Republic of South Africa.

49. Received for publication June 1, 1982.

50. Accepted for publication February 16, 1983.

0031-3998/83/1710-0839\$02.00/0

PEDIATRIC RESEARCH

Copyright $\odot 1983$ International Pediatric Research Foundation, Inc.

Vol. 17 , No. 10,1983

Printed in U.S.A.

\section{Letter to the Editor}

\section{REUBEN STEINHERZ, ${ }^{(6)}$ JANET E. GRAEBER, AND} RODNEY E. ULANE

Department of Pediatrics " $A$ " and Medical Genetic Unit, Sackler School of Medicine, Tel Aviv University and Beilinson Medical Center, Petah Tikva Israel (RS) and Neonatal and Pediatric Medicine Branch, National Institute of Child Health and Human Development, National Institutes of Health, Bethesda, Maryland USA (J.E.G. and R.E.V.)

Cuezva et al. (1) in a very comprehensive report described the effects of streptozotocin-induced maternal diabetes on alterations in the fetal plasma concentrations of glucose and insulin as well as many other parameters. According to this report "... the plasma insulin concentrations were significantly higher in the two groups of diabetic rats then in the normal pups at birth" and furthermore plasma insulin concentrations in the newborns of the diabetic mothers remained significantly higher than in the age-matched normal pups during $4 \mathrm{~h}$ of study postnatally. Recently we looked at the insulin receptors in the developing fetal lung (3) and conducted a comparative study of insulin receptors in the developing fetal lung of normal and streptozotocin induced diabetic pregnancies in rats $(4,5)(60 \mathrm{mg} / \mathrm{kg}$ streptozotocin injected intraperitoneally at 7 days of gestation). We measured plasma glucose and insulin concentrations during pregnancy period, birth and 10 days and 3 months after delivery. The relevant data are shown in Table 1. Our data as emerged from these experiments (4) oppose in a way Cuezva et al. (1) findings and add to the perplexity of drawing a parallel between newborn of human diabetic mother to streptozotocin-induced diabetic rats. In our experience fetal body weight was almost identical in the control and diabetic pregnancies
Table 1. Maternal, fetal, and newborn serum glucose and insulin concentration in streptozotocin-treated and control rats

\begin{tabular}{ccc}
\hline & Control $^{1}$ & Streptozotocin-treated \\
\hline $\begin{array}{c}\text { Maternal } \\
\text { Blood glucose } \\
(\mathrm{mM})\end{array}$ & $5.4 \pm 0.5$ & $32.1 \pm 2.8$ \\
$\begin{array}{c}\text { Insulin } \\
(\mathrm{ng} / \mathrm{ml})\end{array}$ & $1.2 \pm 0.1$ & $0.2 \pm 0.07$ \\
$\begin{array}{c}\mathrm{Fetal}^{2} \\
\text { Blood glucose }_{(\mathrm{mM})}\end{array}$ & $2.2 \pm 0.1$ & $20.8 \pm 2.2$ \\
$\begin{array}{c}\text { Insulin } \\
(\mathrm{ng} / \mathrm{ml})\end{array}$ & $2.5 \pm 0.2$ & $2.7 \pm 0.3$ \\
$\begin{array}{c}\text { Newborn } \\
\text { Blood glucose } \\
(\mathrm{mM})\end{array}$ & $4.8 \pm 0.4$ & $4.9 \pm 0.4$ \\
$\begin{array}{c}\text { Insulin } \\
(\mathrm{ng} / \mathrm{ml})\end{array}$ & $1.5 \pm 0.1$ & $1.7 \pm 0.2$ \\
\hline
\end{tabular}

${ }^{1}$ The results are the means $\pm S E$ of the number of examinees in each group

${ }^{2}$ Ten pregnant rats and 14 streptozotocin-induced diabetic rats were compared at 21 days of gestational age.

${ }^{3}$ Fetuses at 21 days of gestation were c-sectioned and 12 litters in control group vs 14 litters in experimental group compared.

${ }^{4}$ At age of 10 days of life insulin and glucose compared in 4 litters in each group.

$3.05 \pm 0.6$ versus $4.05 \pm 0.5 \mathrm{~g}$, respectively. The fetal lung net weights for 12 litters in the control group and 14 litters in diabetes group were $110 \pm 52$ versus $105 \pm 27 \mathrm{mg}$, respectively. Our results are similar to those reported by Kervran et al. (2) who found that 
the rat fetuses from severely diabetic pregnancies were incapable of producing insulin at level commensurate with the high blood glucose level. The same patterns of behavior was observed between the two groups in a prolonged postnatal follow-up of 3 months. Once again we looked for differences in the plasma concentrations of insulin and glucose. The results were almost identical: in the control group at age of 3 months glucose level was $5.05 \pm 0.22$ versus $5.44 \pm 0.27 \mathrm{mM}$ for streptozotocin-treated group of newborn. Insulin levels were $1.2 \pm 0.2 \mathrm{ng} / \mathrm{ml}$ versus $1.1 \pm 0.2 \mathrm{ng} / \mathrm{ml}$ for control and diabetic group, respectively. Our findings imply that there was no functional damage to the fetal pancreas as confirmed histologically and immunocytochemically study of fetal pancreases by Cuezva et al. (1). Unfortunately, our findings add some more confusion to the already existing conflicting data and call for further investigations on the streptozotocin induced maternal diabetes in rats and the newborn of the diabetic rats in order to come to a better model which will be as similar as possible to the human infants of diabetic mothers.

\section{REFERENCES AND NOTES}

1. Cuezva, J. M., Burkett, E. S., Kerr, D. S., Rodman, H. M., and Patel, M. S.: The newborn of Diabetic rat. I. Hormonal and metabolic changes in the postnatal period. Pediatr. Res., 16: 632 (1982).

2. Kervran, A., Guillaume, M. and Jost A.: The endocrine pancreas of the fetus from diabetic pregnant rat. Diabetologia, 15: 387 (1978).

3. Ulane, R. E., Graeber, J. E., Hansen, J. W., Luccini, L., and Cornblath, M.: Insulin receptors in the developing fetal lung. Life Sci., 31: 3017 (1982)

4. Ulane, R. E., Steinherz, R., Graeber, J. E., and Cornblath, M.: Streptozotocin induced maternal diabetes and its effect on fetal rat lung insulin receptor finding. Presented at the Society Pediatric Research, Washington, D.C. 1982.

5. Ulane, R. E., Graeber, J. E. and Steinherz, R.: A comparison of insulin receptors in the developing fetal lung of normal and streptozotocin induced diabetic pregnancies. Pediatrics, (In press).

6. Requests for reprints should be addressed to: Reuben Steinherz M.D. Department of Pediatrics "A", Beilinson Medical Center, Petah Tikva, Israel.

\section{Response}

JOSE M. CUEZVA, EDWARD S. BURKETT, DOUGLAS S. KERR, HARVEY M. RODMAN, AND MULCHAND S. PATEL

Departments of Biochemistry, Nutrition, Pediatrics and Medicine and Clinical Research Center, Case Western Reserve University School of Medicine, Cleveland, Ohio, USA

As discussed in our recent publication (1), there are conflicting reports on the effects of chemically induced maternal diabetes in rats on newborn weight and concentrations of plasma and pancreatic insulin. The use of experimental protocols differing in important details as: (i) the dose of streptozotocin or alloxan administered to pregnant rats; (ii) the time after the onset of pregnancy when the agent is administered; (iii) the careful documentation of hyperglycemia throughout gestation; (iv) the timing of delivery; (v) litter size differences; and (vi) insulin treatment schedules have made it difficult to compare data derived from various laboratories.

We determined the effects of streptozotocin on maternal diabetes at varying dosages (i.e., $30-70 \mathrm{mg} / \mathrm{kg}$ body weight). A dose of $30 \mathrm{mg} / \mathrm{kg}$ was not effective in inducing maternal diabetes in our hands. Streptozotocin in doses of $60-70 \mathrm{mg} / \mathrm{kg}$ produced hyperglycemia (mean of $22 \mathrm{mM}$ glucose) but resulted in a high maternal mortality before day 16 of gestation from diabetic ketoacidosis. Therefore we settled on a dose of $45 \mathrm{mg} / \mathrm{kg}$ of streptozotocin administered on day 5 of gestation. In contrast, Steinherz et al. (2) injected $60 \mathrm{mg} / \mathrm{kg}$ of streptozotocin in pregnant rats on day 7 of gestation. The mean blood glucose in their animals was $32.1 \pm 2.8 \mathrm{mM}(576 \mathrm{mg} / \mathrm{dl})$. How many of their animals were in mild ketoacidosis? They provide no data on the effects of such severe hyperglycemia on maternal weight gain during gestation or on fetal weights on different days of gestation. They found no differences in body weights of 21-day-old fetuses of diabetic compared to normal rats $(4.05 \pm 0.5 \mathrm{~g}$ versus $3.05 \pm 0.6 \mathrm{~g})$. The body weights of the 21-day-old fetuses of normal rats in their study appear to be very low to us and may reflect variability in the actual duration of gestation in their animals. Furthermore, the mean body weight of a litter depends upon the number of fetuses in the litter. In our study the mean body weight of 20-day-old fetuses of normal rats was $2.70 \pm 0.12 \mathrm{~g}$. On day 22 of gestation our normal newborns had a mean weight of $5.50 \pm 0.06 \mathrm{~g}$ compared with $5.25 \pm 0.11 \mathrm{~g}(P<0.05)$ for the untreated diabetic offspring (1). Our finding of a reduction in the mean body weight of fetuses of untreated diabetic rats is consistent with previous reports (3-5). Severe maternal diabetes in rats significantly increases the length of gestation and hence influences the body weight of the newborns at the time of natural delivery (6). Untreated diabetic pregnant rats do not resemble the human condition. We found that the body weights of the newborns of insulin treated diabetic rats was significantly higher than that of the offspring of normal rats. This finding mimics the human condition. Steinherz et al. (2) did not study insulin treated animals.

Our objective was to measure the hormonal and metabolic changes in the immediate postnatal period, i.e., from delivery to $6 \mathrm{~h}$ of age. Steinherz et al. (2) measured insulin concentrations at one time only on day 21 of gestation. Plasma insulin concentrations in the fetuses of normal rats in our study decreased from $188.3 \pm 29.6 \mu \mathrm{U} / \mathrm{ml}$ on day 21 of gestation to $59.9 \pm 5.7 \mu \mathrm{U} / \mathrm{ml}$ on day 22 of gestation (Table 1). This observed decline in the concentration of plasma insulin concentrations in normal fetuses on day 22 of gestation confirms the reports of others $(7,8)$. The plasma insulin concentrations measured in 21- and 22-day-old fetuses of untreated and insulin treated diabetic rats are shown in Table 1. In contrast to our findings, the plasma insulin concentrations in the 21-day-old fetuses of normal and diabetic rat were $60.0 \pm 4.8$ and $64.8 \pm 7.2 \mu \mathrm{U} / \mathrm{ml}$ in the study of Steinherz et al. (2). They did not measure the decline in plasma insulin concentrations during the early postnatal period.

Table 1. Effect of maternal hyperglycemia on fetal glucose and insulin concentrations in fetuses during day 21 and 22 of gestation. ${ }^{1}$

\begin{tabular}{lccc}
\hline & $\begin{array}{c}\text { Gesta- } \\
\text { tional }\end{array}$ & \multicolumn{2}{c}{ Fetus } \\
\cline { 3 - 4 } \multicolumn{1}{c}{ Mother's status } & $\begin{array}{c}\text { age } \\
\text { (days) }\end{array}$ & $\begin{array}{c}\text { Plasma } \\
\text { glucose } \\
(\mathrm{mM})\end{array}$ & $\begin{array}{c}\text { Plasma } \\
\text { insulin } \\
(\mu \mathrm{U} / \mathrm{ml})\end{array}$ \\
\hline Normal & 21 & $2.57 \pm 0.19$ & $188.3 \pm 29.6$ \\
Untreated diabetic & 21 & $17.40 \pm 0.54^{4}$ & $116.0 \pm 15.4^{2}$ \\
Insulin treated diabetic & 21 & $2.35 \pm 0.13$ & $153.1 \pm 11.9$ \\
Normal & 22 & $3.94 \pm 0.33$ & $59.9 \pm 5.7$ \\
Untreated diabetic & 22 & $20.00 \pm 0.49^{4}$ & $103.8 \pm 5.1^{4}$ \\
Insulin treated diabetic & 22 & $2.46 \pm 0.22^{3}$ & $139.2 \pm 9.2^{4}$ \\
\hline
\end{tabular}

${ }^{1}$ The results are the means \pm S.E. for fetuses from three to six mothers.

${ }^{2} P<0.01$ compared with normal.

${ }^{3} P<0.005$ compared with normal.

${ }^{4} P<0.001$ comapred with normal. 
Steinherz et al. (2) present insulin concentrations measured in the offspring of diabetic rats at 10 days of life. They find no differences in plasma insulin concentrations between the offspring of normal and diabetic rats. In another study, we recently reported that the concentrations of plasma glucose and insulin in 1-day-old newborns of untreated diabetic rats were undistinguishable from those of age-matched pups of normal rats $(9,10)$. Furthermore, plasma glucose and insulin did not vary significantly in the offspring of diabetic and normal rats 7 and 80 days after delivery. The findings of Steinherz et al. (2) at 10 days of life are consistent with these findings; however, the studies presented in reference 1 measured hormonal and metabolic changes in the newborns of untreated and insulin treated pregnant diabetic rats during the first 6 postnatal $\mathrm{h}$ of life. Steinherz et al. did a different study with other objectives and their data cannot be compared to ours.

\section{REFERENCES AND NOTES}

1. Cuezva, J. M., Burkett, E. S., Kerr, D. S., Rodman, H. M., and Patel, M. S.: The newborn of diabetic rat. I. Hormonal and metabolic changes in the postnatal period. Pediatr. Res., 16: 632 (1982).

2. Steinherz, R., Graeber, J. E., and Ulane, R. E.: The newborn of diabetic rat. Hormonal and Metabolic changes in the postnatal period. Pediatr. Res., in press.

3. Pitkin, R. M. and Van Orden, D. E.: Fetal effects of maternal strepotozotocindiabetes. Endocrinology, 94: 1247 (1974).

4. Kervran, A., Guillaume, M., and Jost, A.: The endocrine pancreas of the fetus from diabetic pregnant rat. Diabetologia, 15: 387 (1978).

5. Erikson, U., Dahlstrom, E., Larson, K. S., and Hellerstrom, C.: Increased incidence of congenital malformations in the offspring of diabetic rats and their prevention by maternal insulin therapy. Diabetes, 31 : 1 (1982).

6. Kim, Y. S., Jatoi, I., and Kim, Y.: Neonatal macrosomia in maternal diabetes. Diabetologia, 18: 407 (1980).

7. Felix, J. M., Sutter, M. T., Sutter, B. Ch. J., and Jacquot, R.: Circulating insulin and tissular reactivity to insulin in the rat during the perinatal period. Horm. Metab. Res., 3: 71 (1971).

8. Watts, C., Gain, K., and Sandin, P. L.: Glucose homeostasis in the developing rat. I. Blood glucose and immunoreactive insulin in the later stages of gestation of the fetal rat. Biol. Neonate, 30: 88 (1976).

9. Caliendo, A. M. and Patel, M. S.: Insulin receptors in hepatocytes from fetal rats are not subjected to down regulation. Presented at the Fed. Am. Soc. Exp. Biol, New Orleans, LA, 1982; also see Fed. Proc. 41 : 1341 (1982).

10. Caliendo, A. M.: Insulin receptors in rat liver during development. Ph.D. Thesis, 1983, Case Western Reserve University, Cleveland, Ohio. 